Front Neuroendocrinol. Author manuscript; available in PMC 2013 January 17.

Published in final edited form as:

Front Neuroendocrinol. 2012 January ; 33(1): 116-125. doi:10.1016/j.yfrne.2011.12.002.

\title{
Cytokines and brain excitability
}

\author{
Michael A. Galic, Kiarash Riazi, and Quentin J. Pittman* \\ Hotchkiss Brain Institute, Snyder Institute of Infection, Immunity and Inflammation, and Alberta \\ Children's Hospital Research Institute, Department of Physiology and Pharmacology, Faculty of \\ Medicine, University of Calgary, Health Sciences Centre, 3330 Hospital Dr. NW, Calgary, Alberta, \\ Canada T2N 4N1
}

\begin{abstract}
Cytokines are molecules secreted by peripheral immune cells, microglia, astrocytes and neurons in the central nervous system. Peripheral or central inflammation is characterized by an upregulation of cytokines and their receptors in the brain. Emerging evidence indicates that pro-inflammatory cytokines modulate brain excitability. Findings from both the clinical literature and from in vivo and in vitro laboratory studies suggest that cytokines can increase seizure susceptibility and may be involved in epileptogenesis. Cellular mechanisms that underlie these effects include upregulation of excitatory glutamatergic transmission and downregulation of inhibitory GABAergic transmission.
\end{abstract}

\section{Keywords}

Cytokine; Inflammation; Seizure; Epilepsy; Synapse; Interleukin; Tumor necrosis factor a; Chemokine; Lipopolysaccharide; Febrile convulsion

\section{Introduction to cytokines}

Cytokines are signaling proteins secreted primarily by cells of the immune system, including monocytes, macrophages (e.g. Kupffer cells, microglia), lymphocytes (B and T cells), and vascular endothelial cells that signal the detection of pathogens and activate cellular networks to initiate the appropriate immunological responses. There are many classes of cytokines including numerous interleukins, lymphokines, chemokines, hematopoietins, interferons, as well as members of the platelet derived growth factor (PDGF), transforming growth factor (TGF) and tumor necrosis factor (TNF) families. In this review we will focus on the interleukins and TNFa, as they have been most extensively investigated in the context of brain function and excitability.

Cytokines play a role in several aspects of normal central nervous system (CNS) function. For example they participate in the regulation of sleep [84] and a variety of neuroendocrine functions [132], plus play important roles in neuronal development [17,56,57] and possibly in normal ageing [94]. However, there is increasing attention directed towards understanding

"Corresponding author at: Hotchkiss Brain Institute, Department of Physiology and Pharmacology, Faculty of Medicine, University of Calgary, Calgary, Alberta, Canada. Fax: +1 403283 2700. pittman@ucalgary.ca (Q.J. Pittman). 
cytokines as common mediators of altered CNS function during inflammatory states from bacterial and viral infections of either the brain [71,88], or the periphery [78,82], and disease processes with strong inflammatory components such as colitis, multiple sclerosis, acute liver failure, amyotrophic lateral sclerosis, and Alzheimer's Disease (reviewed in $[20,25,108,128])$. It is also well established that brain trauma including that caused by stroke, results in massive increases in cytokine synthesis that are associated with important effects upon recovery $[3,146]$. In many of these inflammatory CNS pathologies, a common feature is the appearance of other CNS behavioral co-morbidities [170] and an increase in excitability of the brain, sometimes manifested in the form of seizures or of acquired epilepsy [153]. It is possible that the increased excitability leading to increased seizure susceptibility may also be a mechanism underlying neuronal changes in brain areas associated with behavior, but this has received little investigation to date. Thus, while referring to important studies of cytokine participation in several inflammatory states, we will focus this review primarily on cytokine mediation of a number of experimental models of seizures along with reference to clinical data.

\section{Inflammatory models and cytokine production}

Cytokine blood levels are normally low, but they can markedly increase in response to pathogens, inflammation, or tissue injury, as well as in a variety of disease processes like autoimmunity and cancer. Since the inflammatory cascade in many of these entities is difficult to control in an experimental setting, one common method of inducing a predictable course of inflammation in the laboratory is by using lipopolysaccharide (LPS), the pyrogenic component of the outer membrane of gram negative bacteria. Parenteral administration of LPS results in fever, release of several cytokines, and sickness behaviors, followed by full resolution in 6-18 $\mathrm{h}$ depending on the dose. LPS is recognized by the innate immune system via toll-like receptors (TLRs) which are found on many immune cell types such as monocytes and macrophages. TLRs are also found in the brain and localize to the meninges, circumventricular organs, endothelial and perivascular cells and within the brain parenchyma on microglia and possibly astrocytes [86,26,144]. Binding of LPS to its native receptor, TLR-4, activates an intracellular cascade that ultimately causes translocation of NFKB to the nucleus where it initiates transcription of cytokines that are both pro[interleukin (IL)-1 $\beta$, IL-6 and TNFa] and anti- [IL-1 receptor antagonist (ra), IL-10] inflammatory in nature $[24,30]$.

Another common experimental inflammatory model utilizes polyinosinic:polycytidylic acid (PolyI:C), a synthetic double stranded RNA molecule that activates TLR-3 and thereby mimics a viral fever [100]. For the most part, the cellular sequelae are similar to TLR-4 activation by LPS in terms of cytokine generation and physiological effects [70], although activation of TLR-3 also results in generation of interferons [105]. There are also a number of other TLRs such as TLR-2 and 6, each with specific ligands (e.g. lipoteichoic acid and diacyl lipopeptides, respectively) that signal to the brain in much the same way as TLR-3 and 4 described above, and the available evidence suggest that they also activate similar cascades of cytokine production with similar physiological effects as LPS and Poly I:C [73]. 


\section{Peripheral inflammatory signaling to the brain}

Detection of a peripheral immune response occurs via vagal afferents, circumventricular organs, and directly at the blood brain barrier (BBB) [13]. For most systemic inflammatory responses, signaling at the BBB appears to be the dominant means by which the brain responds to peripheral signals; endothelial and perivascular cells synthesize prostaglandin $\mathrm{E}_{2}$ $[59,138,144]$ which diffuses into the parenchyma to stimulate heat conservation and production pathways in the hypothalamus and cause fever [90,134]. In addition, neurons controlling endocrine function also respond to prostaglandins, most notably the corticotrophin releasing factor neurons in the paraventricular nucleus that stimulate adrenocorticotrophic hormone release from the pituitary and adrenal secretion of corticosteroids [79].

In addition, there is now good evidence for movement of leukocytes through a largely intact BBB during peripheral inflammation. This is thought to occur through the activation of the cerebral endothelium in the presence of pro-inflammatory messengers [120]. This increases endothelial cell expression of adhesion factors that are critical for cellular recruitment into tissues. These adhesion molecules include selectins and integrins that facilitate the extravasation of leukocytes through the endothelium and into the brain. Recent evidence suggests that TNFa may be critical in promoting the leukocyte-endothelial interactions, through microglial expression of monocyte chemoattractant protein and the subsequent movement of monocytes into the brain during peripheral inflammation $[31,80]$.

There is unequivocal evidence that peripheral inflammation causes a "mirror" inflammatory response in the CNS, characterized by additional synthesis and action of cytokines within the brain $[89,117-119,127,130,135,156,159]$. Although the precise mechanisms responsible for CNS synthesis of cytokines are not entirely delineated, the cytokines ultimately produced in the brain can be from several sources including microglia, invading inflammatory cells, microvessel endothelial cells, pericytes, choroid plexus, astrocytes

$[126,143,158,21,44,104,171]$ and even neurons where cytokines can be constitutively expressed $[18,52,129,142,172]$. Cytokine production by microglia is related to a characteristic morphological change (ramified to amoeboid) associated with their activation state that can be readily visualized with appropriate staining [45]. Receptors for cytokines are also present in the CNS, with localization on vascular endothelial and perivascular cells, microglia, astrocytes and neurons $[42,47,53,106]$.

Peripheral inflammation is but one example of a process that initiates cytokine production. As the brain possess TLRs of various subtypes, direct inflammation of the brain, for example during encephalitis will also upregulate cytokine production [55,76]. In fact, almost any pathological process in the brain appears to be accompanied by, and exacerbated by cytokine generation; these include traumatic brain injury [77], epileptic seizures [162], ischemia [36,33], multiple sclerosis [25] and neurodegenerative diseases such as Alzheimer's Disease [41]. While each of these conditions has unique pathologies and behavioral correlates, a common feature of all of them is the higher prevalence of seizures or reduced threshold for induction of seizures. Thus we will now focus upon the evidence implicating cytokines in seizures. 


\section{Cytokines, seizures and epilepsy}

The evidence is now overwhelming that epilepsy is associated with inflammation and with elevated levels of cytokines. Virtually all of the pro-inflammatory cytokines are elevated in tissue or cerebral spinal fluid (CSF) from patients with chronic seizure disorders (rev. in [4]). For example, some types of medically intractable epilepsy arising from focal cortical malformations are associated with both increased gene expression [15] and elevated levels of pro-inflammatory cytokines in the CNS [16,29,74,121]. Moreover, in surgical tissue samples from patients with temporal lobe epilepsy where there are pathological features of hippocampal sclerosis (a condition of gliosis and neuronal loss), Vezzani and colleagues [122] have reported both activated microglial cells and increased cytokines. Cytokine levels in the CSF of patients with seizures correlate with both seizure occurrence and duration [91,92,111]. A number of studies have also explored the involvement of cytokines in febrile convulsions in children but there is still no consensus regarding the risk that febrile seizures pose on the development of adult epilepsy (rev in $[39,125]$ ).

Experimental studies in rodents have also reported a strong association between elevated CNS levels of cytokines or of increased expression of cytokine mRNA and increased seizure susceptibility $[9,32,35,166]$. Seizures elicited by convulsants in either mature $[103,157,161]$ or immature [145] rats showed increases in CNS cytokine levels or cytokine expression (Fig. 1). With the use of other immature rodent models of febrile seizures, some groups have shown temporary increases in cytokine levels after febrile seizures that return to control levels within 48 h [40,65] (Fig. 2). Similarly, rats subjected to status epilepticus (a state of persistent seizure) by electrical stimulation of the hippocampus [32] or those that had been kindled (condition whereby seizures appear after repeated subthreshold stimulation of the brain) by amygdala stimulation [115] also showed increased expression of both pro- and anti-inflammatory cytokines. Most recently, it was reported that a rat model of absence seizures, the Genetic Absence Epilepsy Rat, has elevated IL-1 $\beta$ in the cortex [1].

In addition to the persuasive evidence that seizure activity itself causes cytokine synthesis in the brain (rev in [162]), seizures also upregulate IL-1 $\beta$ receptor type 1 [124], in part via release of the molecule High Mobility Group Box 1 (HMGB1) that activates brain TLR-4 and TLR-2 (with consequent activation of cytokine synthesis) and potentiates the activity of pro-inflammatory cytokines $[99,110]$. However, the findings that cytokines and cytokine receptors are elevated in association with seizure activity is not necessarily evidence that they are players in terms of initiating or augmenting the enhanced excitability. To partially address this criticism, investigators have carefully examined the time course of cytokine generation; the observations that cytokines are already elevated at the onset of seizures raises the likelihood that they may be causal $[65,162]$. The direct evidence came from studies looking at over-expression of cytokines in transgenic animals where overt seizures were seen in the absence of precipitating toxins [22,116].

The effect of pro-inflammatory cytokines on the brain is consistently observed to be proconvulsant. Although direct exogenous cytokine application to the brain in vivo does not usually precipitate a seizure itself, it generally facilitates the development of a seizure to other insults that encourage seizure activity $[9,27,38,65,161,163]$. Similarly, peripheral 
inflammation that is known to induce central cytokines, or direct inflammation of the brain via targeting of either TLR-4 or other TLRs also enhances seizures or reduces the threshold to seizurogenic stimuli $[5,6,63,63,95,99,127,131,139]$. Even more importantly, blockade of cytokine action in the brain, for example with exogenous application of IL-1ra (the natural antagonist to IL-1 $\beta$ ), or by enhancing its endogenous expression, interferes with seizures, or reduces their severity in many different seizure models $[65,131,163,164]$. Similarly, immunoneutralization of $\mathrm{TNFa}$ in the brain reduces heightened seizure susceptibility associated with colitis, a chronic peripheral inflammation of the colon [127] (Fig. 3). Animals with genetic deficiency in the production of IL-1 [38], or animals in which IL-1 $\beta$ production is blocked by inhibition of the caspase involved in its synthesis $[98,123]$, exhibit a reduction in seizures.

Inflammation and cytokine release has been suspected also to participate in the very process of epileptogenesis $[40,64,122]$. In different models of febrile seizures, cytokines are elevated acutely [40,65] or chronically [40] and cause either augmented brain excitability [66], or frank spontaneous seizures to occur [37]. Subsequently, it was shown that inflammation in the postnatal period, whether caused by peripheral LPS alone [54], hyperthermic seizures [40], a combination of the two [7] or direct activation of brain TLR-3 [55] caused brain cytokines to increase and a long lasting state of increased brain excitability in adult rats.

\section{Cellular and molecular effects of cytokines on neuronal excitability}

Because of the widespread actions of cytokines in the brain, there have been intensive electrophysiological and pharmacological investigations of their cellular actions over the past 20 years. While this review will focus upon cytokine actions on neuronal excitability, it is important to note that cytokine receptors exist on non- neuronal cells as well. Thus there have been extensive investigations of their electrophysiological effects upon microglia [141] as well as studies of their effects upon astrocytes [46,97]. With respect to neurons, cytokines have profound effects upon synaptic plasticity, especially in the hippocampus [112,113], as well as direct membrane and synaptic effects on CNS neurons, including those involved in central autonomic control (fever) [34,136,151,169], gastrointestinal control [69] and neuroendocrine control $[47,48,132]$. The electrophysiological effects of a wide variety of cytokines have been extensively reviewed $[50,81,101,102,140]$ and these comprehensive reviews should be consulted for detailed information. In the following section we will focus in particular upon actions of pro-inflammatory cytokines that may help to understand their role in increasing neuronal excitability.

IL-1 $\beta$ activity has been most extensively investigated in the context of its pro-convulsive effects, with most studies focused on the acutely prepared hippocampal slice taken from juvenile, post-weaning rodents. In this regard, it is an important, but usually overlooked fact, that slicing the brain itself constitutes a major trauma. Given that trauma is a well known inducer of cytokine production [3], it is not surprising that, of 17 cytokine mRNAs examined within $3 \mathrm{~h}$ of slicing and maintained in vitro under standard slice conditions, 3 were upregulated (including IL-1 $a$ and IL-1 $\beta$ ) and 4 were downregulated (including IL-1ra). Thus it is likely that many of the cellular changes reported are in the context of background cytokine 'tone'. However, an alternate approach is to examine cytokine actions in cultured 
neurons that are normally harvested from late gestation fetuses (day 18-19) and incubated for 10-20 days, where one would suspect the traumatic effects of the culturing procedure would be mitigated during that time. Nonetheless, as cytokines play important roles in the development of the nervous system [83], this approach also has limitations, as the rodent brain at this time is still very immature and developmental trajectories involving cytokine action will undoubtedly be altered in these cultures.

Acute IL-1 $\beta$ application appears to have little if any effect upon resting membrane potential, although active, regenerative currents have been reported to be altered. In hippocampal CA1 neurons, IL-1 $\beta$ at low doses ( $\leq \mathrm{ng} / \mathrm{mL}$ ) reversibly inhibited voltage dependent calcium currents via a protein kinase $C$ mediated action [114]. If similar effects were to take place at the synapse, this could cause a reduction in transmitter release. Support for this possibility comes from reports that low levels of IL-1 $\beta$ decrease intracellular calcium in cortical synaptosomes [23]. In this regard, in vitro studies have examined IL-1 $\beta$ modulation of gamma-amino butyric acid (GABA) and glutamate release from hippocampal slices, but the predominant effect was a dose-dependent $(1-35 \mathrm{ng} / \mathrm{mL})$ increase in calcium-dependent glutamate and GABA release [175]. Thus it is possible that the effects of IL-1 $\beta$ on neurotransmitter release are dependent on concentration whereby higher levels are associated with increased transmitter release. Such dichotomy in function also helps explain why low levels of cytokines that are released during fever appear to be associated with sickness behaviors characterized by lethargy and decreased activity [14,83], while higher levels may enhance neuronal excitability. In addition, whatever the cellular mechanism, it is important to note that an identical cellular action on an inhibitory interneuron and an excitatory output neuron will have very different effects on the circuit output, depending upon the site of action.

In terms of mechanism of action, one potentially interesting hypothesis is that IL- $1 \beta$ could affect a depolarizing, hyperpolarization-activated cationic current known as $I_{h}$. As previously discussed, IL-1 $\beta$ has been shown to be important in epileptogenesis after neonatal seizures [40]. These same investigators have also reported that there are profound alterations in the properties of $I_{\mathrm{h}}$ after the neonatal seizures [19]. To the best of our knowledge, no one to date as specifically addressed the question of whether or not cytokines regulate the properties of this current.

The most promising studies on cellular actions of IL- $1 \beta$ have examined its effects on synaptic signaling. With respect to glutamate receptors, it is the alpha-amnio-3-hydroxy-5methyl-4-isoxazole-propionic acid (AMPA) receptor that mediates the majority of excitatory transmission. Incubation of cultured hippocampal neurons for $1 \mathrm{~h}$ with $10-50 \mathrm{ng} / \mathrm{mL}$ of IL-1 $\beta$ decreased surface expression of AMPA receptors. This effect was receptor mediated, independent of synaptic transmitter release and associated with a calcium-dependent reduction of thephosphorylationoftheGluR1 subunit of the AMPAreceptor [87]. This action could account for the previously observed small reduction in synaptic strength seen at the Schaffer collateral-CA1 excitatory synapse of hippocampal slices [12].

A more likely target for the excitatory effects of IL- $1 \beta$ is its action at the N-methyl-Daspartate (NMDA) receptor. This receptor is normally activated under conditions of intense 
activity when the voltage dependent block is relieved by depolarization of the cell. This is the state that would exist in a cell in the presence of depolarizations caused by convulsants or by high frequency activity and it is the condition where IL-1 $\beta$ has been shown to be effective in vivo.

Pretreatment of hippocampal cultures with low doses of IL-1 $\beta$ caused an upregulation of NMDA receptor-mediated calcium levels in the post synaptic cell via an activation of a tyrosine kinase that phosphorylates the NR2B subunit of the NMDA receptor [165] (Fig. 4). IL-1 $\beta$ signaling also appears to involve a ceramide mediator [9] and, in neurons (but not glia), activation of the mitogen activated protein kinase pathways [147]. Activation of these pathways most likely also mediates transcriptional changes. In this respect, it is interesting that early, neonatal inflammation causes long lasting alterations in subunit expression of several NMDA receptor subunits [62].

These interactions with NMDA mediated transmission are the most likely mechanism for the IL- $1 \beta$ augmentation of seizures. However a number of other actions of IL- $1 \beta$ could also be important. For example, glutamate uptake by astrocytes is impaired by cytokines, an effect that would increase excitatory transmission [72,173]. In addition, acutely applied IL-1 $\beta$ dose dependently decreases $\mathrm{GABA}_{\mathrm{A}}$ mediated potentials in cultured hippocampal neurons [167]. In contrast, chronic LPS exposure in cultured hippocampi caused an IL-1 $\beta$-mediated upregulation of GABA potential amplitude [67], but this might be due to a compensatory mechanism as it occurred after cytokine levels had returned to baseline.

TNFa has also been shown to affect neuronal excitability. In cultured hippocampal neurons, long term incubation with TNFa causes increases in L-type calcium currents [51] but the same authors reported that it decreased intracellular calcium elevations elicited by application of glutamate agonists. To the best of our knowledge, the mechanisms underlying these disparate responses have not been elucidated. Other in vitro studies have shown that TNFa augments glutamatergic transmission both in the hippocampal slice and in cultures $[60,152]$. Recent work from our lab indicates that elevation within the brain of TNFa due to peripheral inflammation also increases excitability in a TNFa dependent manner. This was observed both in vivo and in hippocampal slices obtained from animals with a peripheral inflammation, experimentally-induced colitis [127]. Intracerebroventricular injection of TNFa alone into the brain is capable of increasing seizure susceptibility in normal animals (Fig. 3). This work is in keeping with a large body of data that indicates that TNFa augments glutamatergic transmission throughout the CNS (rev in [68,112]). The likely mechanism for this is an action of TNFa to increase the surface expression of AMPA receptors $[10,150]$. Furthermore it is a particular subtype of AMPA receptors that is inserted, namely that which lacks the GluR2 subunit $[93,109,149]$ (Fig. 5). This is important as AMPA receptors lacking this subunit allow calcium entry when activated, and this can lead to changes in gene expression as well as cytotoxicity [11]. While this action to increase AMPA receptor expression will result in augmented excitatory transmission under inflammatory conditions, there is also evidence that TNFa secreted by glial cells may function to modify synapses under non-inflammatory conditions. In a process known as synaptic scaling, neurons subjected to reduced levels of excitatory inputs can upregulate (or scale up) specific synapses to maintain a constant level of network activity $[150,155]$. In a 
still unknown manner (but likely involving sampling of extracellular glutamate), glial cells somehow detect low levels of neuronal activity and after about $24 \mathrm{~h}$ begin to release TNFa. The ability of neurons to alter their level of excitatory synaptic inputs is dependent upon this glial derived TNFa, as blockade of TNFa signaling prevented or reversed this effect [148]. It is possible that TNFa released during inflammation may be simply an enhancement of this process or that the usual feedback mechanisms [154] that might precisely regulate the magnitude of synaptic scaling may be abrogated during inflammation.

Although earlier studies using fluorescent microscopy did not detect interactions between TNFa and NMDA receptor localization [10], more recent studies using both anatomical and electrophysiological approaches reported a ceramide-dependent effect of TNFa to cause phosphorylation of the NR1 subunit of the NMDA receptor and an increase in its surface expression [168]. In addition to the actions of TNFa to cause increased surface expression of glutamate receptors, it also induces endocytosis of $\mathrm{GABA}_{\mathrm{A}}$ receptors and thus reduces inhibitory drive [149]. As TNFa can directly affect glutamate uptake and release from glial cells $[49,137]$, one can readily appreciate that its actions on glial cells and on synaptic glutamate and GABA receptors can cause profound changes in excitability and possibly long term transcriptional changes.

Among the long term changes that are affected by cytokines is a profound action on long term cellular plasticity, including both long term potentiation and long term depression. In general, both TNFa (reviewed in [2,112] and IL-1 $\beta$ (reviewed in [113]) inhibit these changes that occur in hippocampal slices after stimulation of glutamate synapses at particular frequencies. As both long term potentiation and long term depression are thought to be cellular correlates of learning, the inhibitory action of cytokines on these phenomena could have relevance for some of the co-morbid cognitive changes associated with seizures and inflammation in general $[58,153]$.

Compared to the body of work on TNFa and IL-1 $\beta$, there has been much less attention directed to other pro-inflammatory cytokines. Whereas chronic IL-6 has been shown to alter electro-physiological and synaptic properties in the cerebellum [61], little is known of its actions in areas implicated in seizure generation, although chronic exposure of hippocampal cultures to IL-6 was reported to reduce both Group-II metabotropic glutamate receptors and L-type calcium channels [160].

Another subclass of cytokines, called chemokines, may also be important in the increased cellular excitability associated with inflammation, as they are upregulated under inflammatory conditions and they have chemoattractant properties to promote movement of immune cells into the brain. There is considerable evidence that they play a physiological role in neuroendocrine function [132] and may thus be a new class of neuromodulator $[43,133]$. In this context, it appears that they can also augment neuronal transmission in the hippocampus. The chemokine CXCL10 elicits elevations in intracellular calcium and enhanced synaptic activity [107] as well as increased levels of ERK1/2, CREB and NFKB [8] in hippocampal cultures. Another chemokine, CCL2 (also known as monocyte chemotactic protein-1) causes enhanced excitatory post synaptic currents in the Schaffer collateral pathway of the hippocampus in vitro [174], possibly via a p38 MAP kinase 
pathway [28]. With chronic exposure to the chemokine, CCL3, changes in NMDA-evoked calcium currents and increased NMDA receptors have been observed in culture [85]. It is interesting that despite these profound cellular, synaptic and electrophysiological effects, possible roles for chemokines in seizure generation have been primarily limited to augmenting neutrophil and macrophage infiltration into brain $[75,96]$.

\section{Conclusion and perspectives}

The functional diversity of cytokines has far surpassed their limited role as simple immune system messengers. Like other passing dogmas in Neuroimmunology, such as the view that the brain is an immune privileged site, the role of cytokines in physiological and pathological activity of the brain has expanded. However, the important consideration is how to harness this knowledge and funnel it towards alleviation or treatment of neurological disorders such as epilepsy. In this regard, it is likely that new anti-inflammatory drugs will target cytokines to not only control epilepsy, but also to alleviate the multiple co-morbid issues that arise with inflammatory diseases.

\section{Acknowledgments}

This work was supported by the Canadian Institutes of Health Research, the Crohn's and Colitis Foundation of Canada Chair in IBD Research and the Natural Sciences and Engineering Research Council of Canada and by personnel support grants from the Alberta Heritage Foundation for Medical Research and the Savoy Foundation.

\section{References}

1. Akin D, Ravizza T, Maroso M, Carcak N, Eryigit T, Vanzulli I, Aker RG, Vezzani A, Onat FY. IL-1beta is induced in reactive astrocytes in the somatosensory cortex of rats with genetic absence epilepsy at the onset of spike-and-wave discharges, and contributes to their occurrence. Neurobiol Dis. 2011; 44:259-269. [PubMed: 21645619]

2. Albensi BC, Mattson MP. Evidence for the involvement of TNF and NF-kappaB in hippocampal synaptic plasticity. Synapse. 2000; 35:151-159. [PubMed: 10611641]

3. Allan SM, Tyrrell PJ, Rothwell NJ. Interleukin-1 and neuronal injury. Nat Rev Immunol. 2005; 5:629-640. [PubMed: 16034365]

4. Aronica E, Crino PB. Inflammation in epilepsy: clinical observations. Epilepsia. 2011; 52(Suppl 3): 26-32. [PubMed: 21542843]

5. Auvin S, Mazarati A, Shin D, Sankar R. Inflammation enhances epileptogenesis in the developing rat brain. Neurobiol Dis. 2010; 40:303-310. [PubMed: 20600912]

6. Auvin S, Shin D, Mazarati A, Nakagawa J, Miyamoto J, Sankar R. Inflammation exacerbates seizure-induced injury in the immature brain. Epilepsia. 2007; 48(Suppl 5):27-34.

7. Auvin S, Shin D, Mazarati A, Sankar R. Inflammation induced by LPS enhances epileptogenesis in immature rat and may be partially reversed by IL1RA. Epilepsia. 2010; 51(Suppl 3):34-38. [PubMed: 20618397]

8. Bajova H, Nelson TE, Gruol DL. Chronic CXCL10 alters the level of activated ERK1/2 and transcriptional factors CREB and NF-kappaB in hippocampal neuronal cell culture. J Neuroimmunol. 2008; 195:36-46. [PubMed: 18329727]

9. Balosso S, Maroso M, Sanchez-Alavez M, Ravizza T, Frasca A, Bartfai T, Vezzani A. A novel nontranscriptional pathway mediates the proconvulsive effects of interleukin-1beta. Brain. 2008; 131:3256-3265. [PubMed: 18952671]

10. Beattie EC, Stellwagen D, Morishita W, Bresnahan JC, Ha BK, von Zastrow M, Beattie MS, Malenka RC. Control of synaptic strength by glial TNFalpha. Science. 2002; 295:2282-2285. [PubMed: 11910117] 
11. Beattie MS, Ferguson AR, Bresnahan JC. AMPA-receptor trafficking and injury-induced cell death. Eur J Neurosci. 2010; 32:290-297. [PubMed: 20646045]

12. Bellinger FP, Madamba S, Siggins GR. Interleukin 1 beta inhibits synaptic strength and long-term potentiation in the rat CA1 hippocampus. Brain Res. 1993; 628:227-234. [PubMed: 8313151]

13. Blatteis, CM. The onset of fever: new insights into its mechanism. In: Hari, SS., editor. Progress in Brain Research Neurobiology of Hyperthermia. Elsevier; 2007. p. 3-14.

14. Bluthe RM, Pawlowski M, Suarez P, Parnet P, Pittman Q, Kelley KW, Dantzer R. Synergy between tumor necrosis factor a and interleukin-1 in the induction of sickness behaviour in mice. Psychoneuroendocrinology. 1994; 19:197-207. [PubMed: 8190839]

15. Boer K, Crino PB, Gorter JA, Nellist M, Jansen FE, Spliet WG, van Rijen PC, Wittink FR, Breit TM, Troost D, Wadman WJ, Aronica E. Gene expression analysis of tuberous sclerosis complex cortical tubers reveals increased expression of adhesion and inflammatory factors. Brain Pathol. 2010; 20:704-719. [PubMed: 19912235]

16. Boer K, Jansen F, Nellist M, Redeker S, van den Ouweland AM, Spliet WG, van Nieuwenhuizen $\mathrm{O}$, Troost D, Crino PB, Aronica E. Inflammatory processes in cortical tubers and subependymal giant cell tumors of tuberous sclerosis complex. Epilepsy Res. 2008; 78:7-21. [PubMed: 18023148]

17. Boulanger LM. Immune proteins in brain development and synaptic plasticity. Neuron. 2009; 64:93-109. [PubMed: 19840552]

18. Breder CD, Hazuka C, Ghayur T, Klug C, Huginin M, Yasuda K, Teng M, Saper CB. Regional induction of tumor necrosis factor alpha expression in the mouse brain after systemic lipopolysaccharide administration. Proc Natl Acad Sci USA. 1994; 91:11393-11397. [PubMed: 7972071]

19. Brewster AL, Bernard JA, Gall CM, Baram TZ. Formation of heteromeric hyperpolarizationactivated cyclic nucleotide-gated (HCN) channels in the hippocampus is regulated by developmental seizures. Neurobiol Dis. 2005; 19:200-207. [PubMed: 15837575]

20. Butterworth RF. Neuroinflammation in acute liver failure: mechanisms and novel therapeutic targets. Neurochem Int. 2011; 59:830-836. [PubMed: 21864609]

21. Buttini M, Boddeke H. Peripheral lipopolysaccharide stimulation induces interleukin-1 beta messenger RNA in rat brain microglial cells. Neuroscience. 1995; 65:523-530. [PubMed: 7777165]

22. Campbell IL, Stalder AK, Akwa Y, Pagenstecher A, Asensio VC. Transgenic models to study the actions of cytokines in the central nervous system. Neuroimmunomodulation. 1998; 5:126-135. [PubMed: 9730678]

23. Campbell V, Lynch MA. Biphasic modulation of intracellular Ca2+ concentration by interleukin-1beta in cortical synaptosomes: involvement of a pertussis toxin-sensitive G-protein and mitogen-activated protein kinase. NeuroReport. 1998; 9:1923-1927. [PubMed: 9674568]

24. Cartmell T, Ball C, Bristow AF, Mitchell D, Poole S. Endogenous interleukin-10 is required for the defervescence of fever evoked by local lipopolysaccharide-induced and Staphylococcus aureusinduced inflammation in rats. J Physiol. 2003; 549:653-664. [PubMed: 12692173]

25. Centonze D, Muzio L, Rossi S, Furlan R, Bernardi G, Martino G. The link between inflammation, synaptic transmission and neurodegeneration in multiple sclerosis. Cell Death Differ. 2010; 17:1083-1091. [PubMed: 19927157]

26. Chakravarty S, Herkenham M. Toll-like receptor 4 on nonhematopoietic cells sustains CNS inflammation during endotoxemia, independent of systemic cytokines. J Neurosci. 2005; 25:17881796. [PubMed: 15716415]

27. Chen Y, Rex CS, Rice CJ, Dube CM, Gall CM, Lynch G, Baram TZ. Correlated memory defects and hippocampal dendritic spine loss after acute stress involve corticotropin-releasing hormone signaling. Proc Natl Acad Sci USA. 2010; 107:13123-13128. [PubMed: 20615973]

28. Cho J, Gruol DL. The chemokine CCL2 activates p38 mitogen-activated protein kinase pathway in cultured rat hippocampal cells. J Neuroimmunol. 2008; 199:94-103. [PubMed: 18584881]

29. Choi J, Nordli DR Jr, Alden TD, DiPatri A Jr, Laux L, Kelley K, Rosenow J, Schuele SU, Rajaram V, Koh S. Cellular injury and neuroinflammation in children with chronic intractable epilepsy. J Neuroinflammation. 2009; 6:38. [PubMed: 20021679] 
30. Conti B, Tabarean I, Andrei C, Bartfai T. Cytokines and fever. Front Biosci. 2004; 9:1433-1449. [PubMed: 14977558]

31. D'Mello C, Le T, Swain MG. Cerebral microglia recruit monocytes into the brain in response to tumor necrosis factoralpha signaling during peripheral organ inflammation. J Neurosci. 2009; 29:2089-2102. [PubMed: 19228962]

32. De Simoni MG, Perego C, Ravizza T, Moneta D, Conti M, Marchesi F, De Luigi A, Garattini S, Vezzani A. Inflammatory cytokines and related genes are induced in the rat hippocampus by limbic status epilepticus. Eur J Neurosci. 2000; 12:2623-2633. [PubMed: 10947836]

33. Denes A, Thornton P, Rothwell NJ, Allan SM. Inflammation and brain injury: acute cerebral ischaemia, peripheral and central inflammation. Brain Behav Immun. 2010; 24:708-723. [PubMed: 19770034]

34. Desson SE, Ferguson AV. Interleukin 1beta modulates rat subfornical organ neurons as a result of activation of a non-selective cationic conductance. J Physiol. 2003; 550:113-122. [PubMed: 12879863]

35. Dhote F, Peinnequin A, Carpentier P, Baille V, Delacour C, Foquin A, Lallement G, Dorandeu F. Prolonged inflammatory gene response following soman-induced seizures in mice. Toxicology. 2007; 238:166-176. [PubMed: 17662515]

36. Downes CE, Crack PJ. Neural injury following stroke: are Toll-like receptors the link between the immune system and the CNS? Br J Pharmacol. 2010; 160:1872-1888. [PubMed: 20649586]

37. Dube C, Richichi C, Bender RA, Chung G, Litt B, Baram TZ. Temporal lobe epilepsy after experimental prolonged febrile seizures: prospective analysis. Brain. 2006; 129:911-922. [PubMed: 16446281]

38. Dube C, Vezzani A, Behrens M, Bartfai T, Baram TZ. Interleukin-1 beta contributes to the generation of experimental febrile seizures. Ann Neurol. 2005; 57:152-155. [PubMed: 15622539]

39. Dube CM, Brewster AL, Richichi C, Zha Q, Baram TZ. Fever, febrile seizures and epilepsy. Trends Neurosci. 2007; 30:490-496. [PubMed: 17897728]

40. Dube CM, Ravizza T, Hamamura M, Zha Q, Keebaugh A, Fok K, Andres AL, Nalcioglu O, Obenaus A, Vezzani A, Baram TZ. Epileptogenesis provoked by prolonged experimental febrile seizures: mechanisms and biomarkers. J Neurosci. 2010; 30:7484-7494. [PubMed: 20519523]

41. Eikelenboom P, Veerhuis R, van Exel E, Hoozemans JJ, Rozemuller AJ, van Gool WA. The early involvement of the innate immunity in the pathogenesis of late-onset Alzheimer's disease: neuropathological, epidemiological and genetic evidence. Curr Alzheimer Res. 2011; 8:142-150. [PubMed: 21345167]

42. Ericsson A, Liu C, Hart RP, Sawchenko PE. Type 1 interleukin-1 receptor in the rat brain: Distribution, regulation, and relationship to sites of IL-1-induced cellular activation. J Comp Neurol. 1995; 361:681-698. [PubMed: 8576422]

43. Fabene PF, Bramanti P, Constantin G. The emerging role for chemokines in epilepsy. J Neuroimmunol. 2010; 224:22-27. [PubMed: 20542576]

44. Fabry Z, Fitzsimmons KM, Herlein JA, Moninger TO, Dobbs MB, Hart MN. Production of the cytokines interleukin 1 and 6 by murine brain microvessel endothelium and smooth muscle pericytes. J Neuroimmunol. 1993; 47:23-34. [PubMed: 8376546]

45. Farber K, Kettenmann H. Physiology of microglial cells. Brain Res Brain Res Rev. 2005; 48:133143. [PubMed: 15850652]

46. Fernandes A, Barateiro A, Falcao AS, Silva SL, Vaz AR, Brito MA, Silva RF, Brites D. Astrocyte reactivity to unconjugated bilirubin requires TNF-alpha and IL-1beta receptor signaling pathways. Glia. 2011; 59:14-25. [PubMed: 20967881]

47. Ferri CC, Ferguson AV. Interleukin-1 beta depolarizes paraventricular nucleus parvocellular neurones. J Neuroendocrinol. 2003; 15:126-133. [PubMed: 12535154]

48. Ferri CC, Yuill EA, Ferguson AV. Interleukin-1beta depolarizes magnocellular neurons in the paraventricular nucleus of the hypothalamus through prostaglandin-mediated activation of a non selective cationic conductance. Regul Pept. 2005; 129:63-71. [PubMed: 15927699]

49. Fine SM, Angel RA, Perry SW, Epstein LG, Rothstein JD, Dewhurst S, Gelbard HA. Tumor necrosis factor alpha inhibits glutamate uptake by primary human astrocytes. Implications for pathogenesis of HIV-1 dementia. J Biol Chem. 1996; 271:15303-15306. [PubMed: 8663435] 
50. Fourgeaud L, Boulanger LM. Role of immune molecules in the establishment and plasticity of glutamatergic synapses. Eur J Neurosci. 2010; 32:207-217. [PubMed: 20946111]

51. Furukawa K, Mattson MP. The transcription factor NF-kappaB mediates increases in calcium currents and decreases in. J Neurochem. 1998; 70:1876-1886. [PubMed: 9572271]

52. Gadient RA, Otten U. Identification of interleukin-6 (IL-6)-expressing neurons in the cerebellum and hippocampus of normal adult rats. Neurosci Lett. 1994; 182:243-246. [PubMed: 7715819]

53. Gadient RA, Otten U. Interleukin-6 and interleukin-6 receptor mRNA expression in rat central nervous system. Ann NY Acad Sci. 1995; 762:403-406. [PubMed: 7668542]

54. Galic MA, Riazi K, Heida JG, Mouihate A, Fournier NM, Spencer SJ, Kalynchuk LE, Teskey GC, Pittman QJ. Postnatal inflammation increases seizure susceptibility in adult rats. J Neurosci. 2008; 28:6904-6913. [PubMed: 18596165]

55. Galic MA, Riazi K, Henderson AK, Tsutsui S, Pittman QJ. Viral-like brain inflammation during development causes increased seizure susceptibility in adult rats. Neurobiol Dis. 2009; 36:343351. [PubMed: 19660546]

56. Giulian D, Young DG, Woodward J, Brown DC, Lachman LB. Interleukin-1 is an astroglial growth factor in the developing brain. J Neurosci. 1988; 8:709-714. [PubMed: 3257519]

57. Golan H, Levav T, Mendelsohn A, Huleihel M. Involvement of tumor necrosis factor alpha in hippocampal development and function. Cereb Cortex. 2004; 14:97-105. [PubMed: 14654461]

58. Gorelick PB. Role of inflammation in cognitive impairment: results of observational epidemiological studies and clinical trials. Ann NY Acad Sci. 2010; 1207:155-162. [PubMed: 20955439]

59. Gosselin D, Rivest S. MyD88 signaling in brain endothelial cells is essential for the neuronal activity and glucocorticoid release during systemic inflammation. Mol Psychiatry. 2008; 13:480497. [PubMed: 18180766]

60. Grassi F, Mileo AM, Monaco L, Punturieri A, Santoni A, Eusebi F. TNF-alpha increases the frequency of spontaneous miniature synaptic currents in cultured rat hippocampal neurons. Brain Res. 1994; 659:226-230. [PubMed: 7820666]

61. Gruol DL, Nelson TE. Purkinje neuron physiology is altered by the inflammatory factor interleukin-6. Cerebellum. 2005; 4:198-205. [PubMed: 16147952]

62. Harre EM, Galic MA, Mouihate A, Noorbakhsh F, Pittman QJ. Neonatal inflammation produces selective behavioural deficits and alters N-methyl-D-aspartate receptor subunit mRNA in the adult rat brain. Eur J Neurosci. 2008; 27:644-653. [PubMed: 18279317]

63. Heida JG, Boisse L, Pittman QJ. Lipopolysaccharide induced febrile convulsions in the rat: shortterm sequelae. Epilepsia. 2004; 45:1-13.

64. Heida JG, Moshe SL, Pittman QJ. The role of interleukin-1beta in febrile seizures. Brain Dev. 2009; 31:388-393. [PubMed: 19217733]

65. Heida JG, Pittman QJ. Causal links between brain cytokines and experimental febrile convulsions in the rat. Epilepsia. 2005; 46:1906-1913. [PubMed: 16393156]

66. Heida JG, Teskey GC, Pittman QJ. Febrile convulsions induced by the combination of lipopolysaccharide and low-dose kainic acid enhance seizure susceptibility, not epileptogenesis, in rats. Epilepsia. 2005; 46:1898-1905. [PubMed: 16393155]

67. Hellstrom IC, Danik M, Luheshi GN, Williams S. Chronic LPS exposure produces changes in intrinsic membrane properties and a sustained IL-beta-dependent increase in GABAergic inhibition in hippocampal CA1 pyramidal neurons. Hippocampus. 2005; 15:656-664. [PubMed: 15889405]

68. Hermann GE, Holmes GM, Rogers RC. TNF(alpha) modulation of visceral and spinal sensory processing. Curr Pharm Des. 2005; 11:1391-1409. [PubMed: 15853670]

69. Hermann GE, Rogers RC. TNFalpha: a trigger of autonomic dysfunction. Neuroscientist. 2008; 14:53-67. [PubMed: 17911224]

70. Hopwood N, Maswanganyi T, Harden LM. Comparison of anorexia, lethargy, and fever induced by bacterial and viral mimetics in rats. Can J Physiol Pharmacol. 2009; 87:211-220. [PubMed: 19295662]

71. Hosking MP, Lane TE. The role of chemokines during viral infection of the CNS. PLoS Pathog. 2010; 6:e1000937. [PubMed: 20686655] 
72. Hu S, Sheng WS, Ehrlich LC, Peterson PK, Chao CC. Cytokine effects on glutamate uptake by human astrocytes. Neuroimmunomodulation. 2000; 7:153-159. [PubMed: 10754403]

73. Hubschle T, Mutze J, Muhlradt PF, Korte S, Gerstberger R, Roth J. Pyrexia, anorexia, adipsia, and depressed motor activity in rats during systemic inflammation induced by the Toll-like receptors-2 and -6 agonists MALP-2 and FSL-1. Am J Physiol Regul Integr Comp Physiol. 2006; 290:R180R187. [PubMed: 16154916]

74. Iyer A, Zurolo E, Spliet WG, van Rijen PC, Baayen JC, Gorter JA, Aronica E. Evaluation of the innate and adaptive immunity in type I and type II focal cortical dysplasias. Epilepsia. 2010; 51:1763-1773. [PubMed: 20345941]

75. Johnson EA, Dao TL, Guignet MA, Geddes CE, Koemeter-Cox AI, Kan RK. Increased expression of the chemokines CXCL1 and MIP-1alpha by resident brain cells precedes neutrophil infiltration in the brain following prolonged soman-induced status epilepticus in rats. J Neuroinflammation. 2011; 8:41. [PubMed: 21535896]

76. Kadhim H, De Prez C, Gazagnes MD, Sebire G. In situ cytokine immune responses in acute disseminated encephalomyelitis: insights into pathophysiologic mechanisms. Hum Pathol. 2003; 34:293-297. [PubMed: 12673567]

77. Kadhim HJ, Duchateau J, Sebire G. Cytokines and brain injury: invited review. J Inten Care Med. 2008; 23:236-249.

78. Katafuchi T, Kondo T, Take S, Yoshimura M. Brain cytokines and the 5-HT system during poly I:C-induced fatigue. Ann NY Acad Sci. 2006; 1088:230-237. [PubMed: 17192569]

79. Kentner AC, Pittman QJ. Minireview: early-life programming by inflammation of the neuroendocrine system. Endocrinology. 2010; 151:4602-4606. [PubMed: 20668021]

80. Kerfoot SM, D’Mello C, Nguyen H, Ajuebor MN, Kubes P, Le T, Swain MG. TNF-alpha-secreting monocytes are recruited into the brain of cholestatic mice. Hepatology. 2006; 43:154-162. [PubMed: 16374849]

81. Koller H, Siebler M, Hartung HP. Immunologically induced electrophysiological dysfunction: implications for inflammatory diseases of the CNS and PNS. Prog Neurobiol. 1997; 52:1-26. [PubMed: 9185232]

82. Konsman JP, Parnet P, Dantzer R. Cytokine-induced sickness behaviour: mechanisms and implications. Trends Neurosci. 2002; 25:154-159. [PubMed: 11852148]

83. Konsman JP, Veeneman J, Combe C, Poole S, Luheshi GN, Dantzer R. Central nervous action of interleukin-1 mediates activation of limbic structures and behavioural depression in response to peripheral administration of bacterial lipopolysaccharide. Eur J Neurosci. 2008; 28:2499-2510. [PubMed: 19087175]

84. Krueger JM, Fang J, Taishi P, Chen Z, Kushikata T, Gardi J. Sleep. A physiologic role for IL-1 beta and TNF-alpha. Ann NY Acad Sci. 1998; 856:148-159. [PubMed: 9917875]

85. Kuijpers M, van Gassen KL, de Graan PN, Gruol D. Chronic exposure to the chemokine CCL3 enhances neuronal network activity in rat hippocampal cultures. J Neuroimmunol. 2010; 229:7380. [PubMed: 20678811]

86. Laflamme N, Rivest S. Toll-like receptor 4: the missing link of the cerebral innate immune response triggered by circulating gram-negative bacterial cell wall components. FASEB J. 2001; 15:155-163. [PubMed: 11149903]

87. Lai AY, Swayze RD, El Husseini A, Song C. Interleukin-1 beta modulates AMPA receptor expression and phosphorylation in hippocampal neurons. J Neuroimmunol. 2006; 175:97-106. [PubMed: 16626814]

88. Lane TE, Hosking MP. The pathogenesis of murine coronavirus infection of the central nervous system. Crit Rev Immunol. 2010; 30:119-130. [PubMed: 20370625]

89. Laye S, Parnet P, Goujon E, Dantzer R. Peripheral administration of lipopolysaccharide induces the expression of cytokine transcripts in the brain and pituitary of mice. Brain Res Mol Brain Res. 1994; 27:157-162. [PubMed: 7877446]

90. Lazarus M, Yoshida K, Coppari R, Bass CE, Mochizuki T, Lowell BB, Saper CB. EP3 prostaglandin receptors in the median preoptic nucleus are critical for fever responses. Nat Neurosci. 2007; 10:1131-1133. [PubMed: 17676060] 
91. Lehtimaki KA, Keranen T, Palmio J, Peltola J. Levels of IL-1beta and IL-1ra in cerebrospinal fluid of human patients after single and prolonged seizures. Neuroimmunomodulation. 2010; 17:19-22. [PubMed: 19816053]

92. Lehtimaki KA, Liimatainen S, Peltola J, Arvio M. The serum level of interleukin-6 in patients with intellectual disability and refractory epilepsy. Epilepsy Res. 2011; 95:184-187. [PubMed: 21530175]

93. Leonoudakis D, Zhao P, Beattie EC. Rapid tumor necrosis factor alpha-induced exocytosis of glutamate receptor 2-lacking AMPA receptors to extrasynaptic plasma membrane potentiates excitotoxicity. J Neurosci. 2008; 28:2119-2130. [PubMed: 18305246]

94. Letiembre M, Hao W, Liu Y, Walter S, Mihaljevic I, Rivest S, Hartmann T, Fassbender K. Innate immune receptor expression in normal brain aging. Neuroscience. 2007; 146:248-254. [PubMed: 17293054]

95. Libbey JE, Kennett NJ, Wilcox KS, White HS, Fujinami RS. Interleukin-6, produced by resident cells of the central nervous system and infiltrating cells, contributes to the development of seizures following viral infection. J Virol. 2011; 85:6913-6922. [PubMed: 21543484]

96. Louboutin JP, Chekmasova A, Marusich E, Agrawal L, Strayer DS. Role of CCR5 and its ligands in the control of vascular inflammation and leukocyte recruitment required for acute excitotoxic seizure induction and neural damage. FASEB J. 2011; 25:737-753. [PubMed: 20940264]

97. Lundborg C, Westerlund A, Bjorklund U, Biber B, Hansson E. Ifenprodil restores GDNF-evoked $\mathrm{Ca}(2+)$ signalling and $\mathrm{Na}(+) / \mathrm{K}(+)$-ATPase expression in inflammation-pretreated astrocytes. $\mathrm{J}$ Neurochem. 2011; 119:686-696. [PubMed: 21883228]

98. Maroso M, Balosso S, Ravizza T, Iori V, Wright CI, French J, Vezzani A. Interleukin-1beta biosynthesis inhibition reduces acute seizures and drug resistant chronic epileptic activity in mice. Neurotherapeutics. 2011; 8:304-315. [PubMed: 21431948]

99. Maroso M, Balosso S, Ravizza T, Liu J, Aronica E, Iyer AM, Rossetti C, Molteni M, Casalgrandi M, Manfredi AA, Bianchi ME, Vezzani A. Toll-like receptor 4 and high-mobility group box-1 are involved in ictogenesis and can be targeted to reduce seizures. Nat Med. 2010; 16:413-419. [PubMed: 20348922]

100. Marshall-Clarke S, Downes JE, Haga IR, Bowie AG, Borrow P, Pennock JL, Grencis RK, Rothwell P. Polyinosinic acid is a ligand for toll-like receptor 3. J Biol Chem. 2007; 282:2475924766. [PubMed: 17573354]

101. Melik-Parsadaniantz S, Rostene W. Chemokines and neuromodulation. J Neuroimmunol. 2008; 198:62-68. [PubMed: 18538863]

102. Miller RJ, Rostene W, Apartis E, Banisadr G, Biber K, Milligan ED, White FA, Zhang J. Chemokine action in the nervous system. J Neurosci. 2008; 28:11792-11795. [PubMed: 19005041]

103. Minami M, Kuraishi Y, Yamaguchi T, Nakai S, Hirai Y, Satoh M. Convulsants induce interleukin-1 beta messenger RNA in rat brain. Biochem Biophys Res Commun. 1990; 171:832837. [PubMed: 1698365]

104. Mitchell K, Yang HY, Berk JD, Tran JH, Iadarola MJ. Monocyte chemoattractant protein-1 in the choroid plexus: a potential link between vascular pro-inflammatory mediators and the CNS during peripheral tissue inflammation. Neuroscience. 2009; 158:885-895. [PubMed: 19032979]

105. Mogensen TH, Paludan SR. Molecular pathways in virus-induced cytokine production. Microbiol Mol Biol Rev. 2001; 65:131-150. [PubMed: 11238989]

106. Nadeau S, Rivest S. Regulation of the gene encoding tumor necrosis factor alpha (TNF-alpha) in the rat brain and pituitary in response in different models of systemic immune challenge. $\mathrm{J}$ Neuropathol Exp Neurol. 1999; 58:61-77. [PubMed: 10068315]

107. Nelson TE, Gruol DL. The chemokine CXCL10 modulates excitatory activity and intracellular calcium signaling in cultured hippocampal neurons. J Neuroimmunol. 2004; 156:74-87. [PubMed: 15465598]

108. Nguyen MD, Julien JP, Rivest S. Innate immunity: the missing link in neuroprotection and neurodegeneration? Nat Rev Neurosci. 2002; 3:216-227. [PubMed: 11994753]

109. Ogoshi F, Yin HZ, Kuppumbatti Y, Song B, Amindari S, Weiss JH. Tumor necrosis-factor-alpha (TNF-alpha) induces rapid insertion of Ca2+-permeable alpha-amino-3-hydroxyl-5-methyl-4- 
isoxazole-propionate (AMPA)/kainate ( $\mathrm{Ca}-\mathrm{A} / \mathrm{K})$ channels in a subset of hippocampal pyramidal neurons. Exp Neurol. 2005; 193:384-393. [PubMed: 15869941]

110. Pedrazzi M, Patrone M, Passalacqua M, Ranzato E, Colamassaro D, Sparatore B, Pontremoli S, Melloni E. Selective proinflammatory activation of astrocytes by high-mobility group box 1 protein signaling. J Immunol. 2007; 179:8525-8532. [PubMed: 18056400]

111. Peltola J, Palmio J, Korhonen L, Suhonen J, Miettinen A, Hurme M, Lindholm D, Keranen T. Interleukin-6 and interleukin-1 receptor antagonist in cerebrospinal fluid from patients with recent tonic-clonic seizures. Epilepsy Res. 2000; 41:205-211. [PubMed: 10962211]

112. Pickering M, Cumiskey D, O'Connor JJ. Actions of TNF-alpha on glutamatergic synaptic transmission in the central nervous system. Exp Physiol. 2005; 90:663-670. [PubMed: 15944202]

113. Pickering M, O’Connor JJ. Pro-inflammatory cytokines and their effects in the dentate gyrus. Prog Brain Res. 2007; 163:339-354. [PubMed: 17765728]

114. Plata-Salaman CR, Ffrench-Mullen JMH. Interleukin-1b inhibits $\mathrm{Ca}^{2+}$ channel currents in hippocampal neurons through protein kinase C. Eur J Pharmacol. 1994; 266:1-10. [PubMed: 8137877]

115. Plata-Salaman CR, Ilyin SE, Turrin NP, Gayle D, Flynn MC, Romanovitch AE, Kelly ME, Bureau Y, Anisman H, McIntyre DC. Kindling modulates the IL-1beta system, TNF-alpha, TGFbeta1, and neuropeptide mRNAs in specific brain regions. Brain Res Mol Brain Res. 2000; 75:248-258. [PubMed: 10686345]

116. Probert L, Akassoglou K, Kassiotis G, Pasparakis M, Alexopoulou L, Kollias G. TNF-alpha transgenic and knockout models of CNS inflammation and degeneration. J Neuroimmunol. 1997; 72:137-141. [PubMed: 9042105]

117. Pyter LM, Pineros V, Galang JA, McClintock MK, Prendergast BJ. Peripheral tumors induce depressive-like behaviors and cytokine production and alter hypothalamic-pituitary-adrenal axis regulation. Proc Natl Acad Sci USA. 2009; 106:9069-9074. [PubMed: 19451634]

118. Qin L, Wu X, Block ML, Liu Y, Breese GR, Hong JS, Knapp DJ, Crews FT. Systemic LPS causes chronic neuroinflammation and progressive neurodegeneration. Glia. 2007; 55:453-462. [PubMed: 17203472]

119. Quan N, Stern EL, Whiteside MB, Herkenham M. Induction of pro-inflammatory cytokine mRNAs in the brain after peripheral injection of subseptic doses of lipopolysaccharide in the rat. J Neuroimmunol. 1999; 93:72-80. [PubMed: 10378870]

120. Ransohoff RM, Kivisakk P, Kidd G. Three or more routes for leukocyte migration into the central nervous system. Nat Rev Immunol. 2003; 3:569-581. [PubMed: 12876559]

121. Ravizza T, Boer K, Redeker S, Spliet WG, van Rijen PC, Troost D, Vezzani A, Aronica E. The IL-1beta system in epilepsy-associated malformations of cortical development. Neurobiol Dis. 2006; 24:128-143. [PubMed: 16860990]

122. Ravizza T, Gagliardi B, Noe F, Boer K, Aronica E, Vezzani A. Innate and adaptive immunity during epileptogenesis and spontaneous seizures: evidence from experimental models and human temporal lobe epilepsy. Neurobiol Dis. 2008; 29:142-160. [PubMed: 17931873]

123. Ravizza T, Lucas SM, Balosso S, Bernardino L, Ku G, Noe F, Malva J, Randle JC, Allan S, Vezzani A. Inactivation of caspase-1 in rodent brain: a novel anticonvulsive strategy. Epilepsia. 2006; 47:1160-1168. [PubMed: 16886979]

124. Ravizza T, Vezzani A. Status epilepticus induces time-dependent neuronal and astrocytic expression of interleukin-1 receptor type I in the rat limbic system. Neuroscience. 2006; 137:301-308. [PubMed: 16289587]

125. Reid AY, Galic MA, Teskey GC, Pittman QJ. Febrile seizures: current views and investigations. Can J Neurol Sci. 2009; 36:679-686. [PubMed: 19960745]

126. Reyes TM, Fabry Z, Coe CL. Brain endothelial cell production of a neuroprotective cytokine, interleukin-6, in response to noxious stimuli. Brain Res. 1999; 851:215-220. [PubMed: 10642846]

127. Riazi K, Galic MA, Kuzmiski JB, Ho W, Sharkey KA, Pittman QJ. Microglial activation and TNFalpha production mediate altered CNS excitability following peripheral inflammation. Proc Natl Acad Sci USA. 2008; 105:17151-17156. [PubMed: 18955701] 
128. Riazi K, Galic MA, Pittman QJ. Contributions of peripheral inflammation to seizure susceptibility: cytokines and brain excitability. Epilepsy Res. 2010; 89:34-42. [PubMed: 19804959]

129. Ringheim GE, Burgher KL, Heroux JA. Interleukin- 6 mRNA expression by cortical neurons in culture: evidence for neuronal sources of interleukin-6 production in the brain. J Neuroimmunol. 1995; 63:113-123. [PubMed: 8550808]

130. Rivest S. Molecular insights on the cerebral innate immune system. Brain Behav Immun. 2003; 17:13-19. [PubMed: 12615045]

131. Rodgers KM, Hutchinson MR, Northcutt A, Maier SF, Watkins LR, Barth DS. The cortical innate immune response increases local neuronal excitability leading to seizures. Brain. 2009; 132:2478-2486. [PubMed: 19567702]

132. Rostene W, Guyon A, Kular L, Godefroy D, Barbieri F, Bajetto A, Banisadr G, Callewaere C, Conductier G, Rovere C, Melik-Parsadaniantz S, Florio T. Chemokines and chemokine receptors: new actors in neuroendocrine regulations. Front Neuroendocrinol. 2011; 32:10-24. [PubMed: 20624414]

133. Rostene W, Kitabgi P, Parsadaniantz SM. Chemokines: a new class of neuromodulator? Nat Rev Neurosci. 2007; 8:895-903. [PubMed: 17948033]

134. Roth J, Rummel C, Barth SW, Gerstberger R, Hubschle T. Molecular aspects of fever and hyperthermia. Immunol Allergy Clin North Am. 2009; 29:229-245. [PubMed: 19389579]

135. Rothwell NJ, Luheshi G, Toulmond S. Cytokines and their receptors in the central nervous system: physiology, pharmacology, and pathology. Pharmacol Ther. 1996; 69:85-95. [PubMed: 8984509]

136. Sanchez-Alavez M, Tabarean IV, Behrens MM, Bartfai T. Ceramide mediates the rapid phase of febrile response to IL-1beta. Proc Natl Acad Sci USA. 2006; 103:2904-2908. [PubMed: 16477014]

137. Santello M, Bezzi P, Volterra A. TNFalpha controls glutamatergic gliotransmission in the hippocampal dentate gyrus. Neuron. 2011; 69:988-1001. [PubMed: 21382557]

138. Saper CB. The dance of the perivascular and endothelial cells: mechanisms of brain response to immune signaling. Neuron. 2010; 65:4-6. [PubMed: 20152108]

139. Sayyah M, Javad-Pour M, Ghazi-Khansari M. The bacterial endotoxin lipopolysaccharide enhances seizure susceptibility in mice: involvement of proinflammatory factors: nitric oxide and prostaglandins. Neuroscience. 2003; 122:1073-1080. [PubMed: 14643773]

140. Schafers M, Sorkin L. Effect of cytokines on neuronal excitability. Neurosci Lett. 2008; 437:188193. [PubMed: 18420346]

141. Schilling T, Nitsch R, Heinemann U, Haas D, Eder C. Astrocyte-released cytokines induce ramification and outward $\mathrm{K}+$ channel expression in microglia via distinct signalling pathways. Eur J Neurosci. 2001; 14:463-473. [PubMed: 11553296]

142. Schobitz B, de Kloet ER, Sutanto W, Holsboer F. Cellular localization of interleukin 6 mRNA and interleukin 6 receptor mRNA in rat brain. Eur J Neurosci. 1993; 5:1426-1435. [PubMed: 8287192]

143. Sebire G, Emilie D, Wallon C, Hery C, Devergne O, Delfraissy JF, Galanaud P, Tardieu M. In vitro production of IL-6, IL-1 beta, and tumor necrosis factor-alpha by human embryonic microglial and neural cells. J Immunol. 1993; 150:1517-1523. [PubMed: 8432992]

144. Serrats J, Schiltz JC, Garcia-Bueno B, Van Rooijen N, Reyes TM, Sawchenko PE. Dual roles for perivascular macrophages in immune-to-brain signaling. Neuron. 2010; 65:94-106. [PubMed: 20152116]

145. Somera-Molina KC, Robin B, Somera CA, Anderson C, Stine C, Koh S, Behanna HA, Van Eldik LJ, Watterson DM, Wainwright MS. Glial activation links early-life seizures and long-term neurologic dysfunction: evidence using a small molecule inhibitor of proinflammatory cytokine upregulation. Epilepsia. 2007; 48:1785-1800. [PubMed: 17521344]

146. Spencer SJ, Mouihate A, Pittman QJ. Peripheral inflammation exacerbates damage after global ischemia independently of temperature and acute brain inflammation. Stroke. 2007; 38:1570 1577. [PubMed: 17395866] 
147. Srinivasan D, Yen JH, Joseph DJ, Friedman W. Cell type-specific interleukin-1beta signaling in the CNS. J Neurosci. 2004; 24:6482-6488. [PubMed: 15269258]

148. Steinmetz CC, Turrigiano GG. Tumor necrosis factor-alpha signaling maintains the ability of cortical synapses to express synaptic scaling. J Neurosci. 2010; 30:14685-14690. [PubMed: 21048125]

149. Stellwagen D, Beattie EC, Seo JY, Malenka RC. Differential regulation of AMPA receptor and GABA receptor trafficking by tumor necrosis factor-alpha. J Neurosci. 2005; 25:3219-3228. [PubMed: 15788779]

150. Stellwagen D, Malenka RC. Synaptic scaling mediated by glial TNF-alpha. Nature. 2006; 440:1054-1059. [PubMed: 16547515]

151. Tabarean IV, Korn H, Bartfai T. Interleukin-1beta induces hyperpolarization and modulates synaptic inhibition in preoptic and anterior hypothalamic neurons. Neuroscience. 2006; 141:1685-1695. [PubMed: 16777343]

152. Tancredi V, D’Arcangelo G, Grassi F, Tarroni P, Palmieri G, Santoni A, Eusebi F. Tumor necrosis factor alters synaptic transmission in rat hippocampal slices. Neurosci Lett. 1992; 146:176-178. [PubMed: 1337194]

153. Tellez-Zenteno JF, Patten SB, Jette N, Williams J, Wiebe S. Psychiatric comorbidity in epilepsy: a population-based analysis. Epilepsia. 2007; 48:2336-2344. [PubMed: 17662062]

154. Turrigiano GG. More than a sidekick: glia and homeostatic synaptic plasticity. Trends Mol Med. 2006; 12:458-460. [PubMed: 16931159]

155. Turrigiano GG, Leslie KR, Desai NS, Rutherford LC, Nelson SB. Activity-dependent scaling of quantal amplitude in neocortical neurons. Nature. 1998; 391:892-896. [PubMed: 9495341]

156. Turrin NP, Gayle D, Ilyin SE, Flynn MC, Langhans W, Schwartz GJ, Plata-Salaman CR. Proinflammatory and anti-inflammatory cytokine mRNA induction in the periphery and brain following intraperitoneal administration of bacterial lipopolysaccharide. Brain Res Bull. 2001; 54:443-453. [PubMed: 11306198]

157. Turrin NP, Rivest S. Innate immune reaction in response to seizures: implications for the neuropathology associated with epilepsy. Neurobiol Dis. 2004; 16:321-334. [PubMed: 15193289]

158. Van Dam AM, Bauer J, Tilders FJH, Berkenbosch F. Endotoxin-induced appearance of immunoreactive interleukin- $1 \mathrm{~b}$ in ramified microglia in rat brain: a light and electron microscopic study. Neuroscience. 1995; 65:815-826. [PubMed: 7609880]

159. Van Dam AM, Bol JG, Gaykema RP, Goehler LE, Maier SF, Watkins LR, Tilders FJ. Vagotomy does not inhibit high dose lipopolysaccharide-induced interleukin-1beta immunoreactivity in rat brain and pituitary gland. Neurosci Lett. 2000; 285:169-172. [PubMed: 10806313]

160. Vereyken EJ, Bajova H, Chow S, de Graan PN, Gruol DL. Chronic interleukin-6 alters the level of synaptic proteins in hippocampus in culture and in vivo. Eur J Neurosci. 2007; 25:3605-3616. [PubMed: 17610580]

161. Vezzani A, Conti M, De Luigi A, Ravizza T, Moneta D, Marchesi F, De Simoni MG. Interleukin-1beta immunoreactivity and microglia are enhanced in the rat hippocampus by focal kainate application: functional evidence for enhancement of electrographic seizures. J Neurosci. 1999; 19:5054-5065. [PubMed: 10366638]

162. Vezzani A, French J, Bartfai T, Baram TZ. The role of inflammation in epilepsy. Nat Rev Neurol. 2011; 7:31-40. [PubMed: 21135885]

163. Vezzani A, Moneta D, Conti M, Richichi C, Ravizza T, De Luigi A, De Simoni MG, Sperk G, Andell-Jonsson S, Lundkvist J, Iverfeldt K, Bartfai T. Powerful anticonvulsant action of IL-1 receptor antagonist on intracerebral injection and astrocytic overexpression in mice. Proc Natl Acad Sci USA. 2000; 97:11534-11539. [PubMed: 11016948]

164. Vezzani A, Moneta D, Richichi C, Aliprandi M, Burrows SJ, Ravizza T, Perego C, De Simoni MG. Functional role of inflammatory cytokines and antiinflammatory molecules in seizures and epileptogenesis. Epilepsia. 2002; 43(Suppl 5):30-35. [PubMed: 12121291]

165. Viviani B, Bartesaghi S, Gardoni F, Vezzani A, Behrens MM, Bartfai T, Binaglia M, Corsini E, Di Luca M, Galli CL, Marinovich M. Interleukin-1beta enhances NMDA receptor-mediated 
intracellular calcium increase through activation of the Src family of kinases. J Neurosci. 2003; 23:8692-8700. [PubMed: 14507968]

166. Voutsinos-Porche B, Koning E, Kaplan H, Ferrandon A, Guenounou M, Nehlig A, Motte J. Temporal patterns of the cerebral inflammatory response in the rat lithium-pilocarpine model of temporal lobe epilepsy. Neurobiol Dis. 2004; 17:385-402. [PubMed: 15571975]

167. Wang S, Cheng Q, Malik S, Yang J. Interleukin-1beta inhibits gamma-aminobutyric acid type A (GABA(A)) receptor current in cultured hippocampal neurons. J Pharmacol Exp Ther. 2000; 292:497-504. [PubMed: 10640285]

168. Wheeler D, Knapp E, Bandaru VV, Wang Y, Knorr D, Poirier C, Mattson MP, Geiger JD, Haughey NJ. Tumor necrosis factor-alpha-induced neutral sphingomyelinase-2 modulates synaptic plasticity by controlling the membrane insertion of NMDA receptors. J Neurochem. 2009; 109:1237-1249. [PubMed: 19476542]

169. Wilkinson MF, Mathison WB, Pittman QJ. Interleukin-IB has excitatory effects on neurons of the bed nucleus of the stria terminalis. Brain Res. 1993; 625:342-346. [PubMed: 8275318]

170. Wittchen HU, Gloster A, Beesdo K, Schonfeld S, Perkonigg A. Posttraumatic stress disorder: diagnostic and epidemiological perspectives. CNS Spectrosc. 2009; 14:5-12.

171. Wong ML, Bongiorno PB, Gold PW, Licinio J. Localization of interleukin-1 beta converting enzyme mRNA in rat brain vasculature: evidence that the genes encoding the interleukin-1 system are constitutively expressed in brain blood vessels. Pathophysiological implications. Neuroimmunomodulation. 1995; 2:141-148. [PubMed: 8646563]

172. Yang HY, Mitchell K, Keller JM, Iadarola MJ. Peripheral inflammation increases Scya2 expression in sensory ganglia and cytokine and endothelial related gene expression in inflamed tissue. J Neurochem. 2007; 103:1628-1643. [PubMed: 17883394]

173. Ye ZC, Sontheimer H. Cytokine modulation of glial glutamate uptake: a possible involvement of nitric oxide. NeuroReport. 1996; 7:2181-2185. [PubMed: 8930985]

174. Zhou Y, Tang H, Liu J, Dong J, Xiong H. Chemokine CCL2 modulation of neuronal excitability and synaptic transmission in rat hippocampal slices. J Neurochem. 2011; 116:406-414. [PubMed: 21105875]

175. Zhu G, Okada M, Yoshida S, Mori F, Ueno S, Wakabayashi K, Kaneko S. Effects of interleukin-1beta on hippocampal glutamate and GABA releases associated with $\mathrm{Ca} 2+$-induced Ca2+ releasing systems. Epilepsy Res. 2006; 71:107-116. [PubMed: 16806825] 

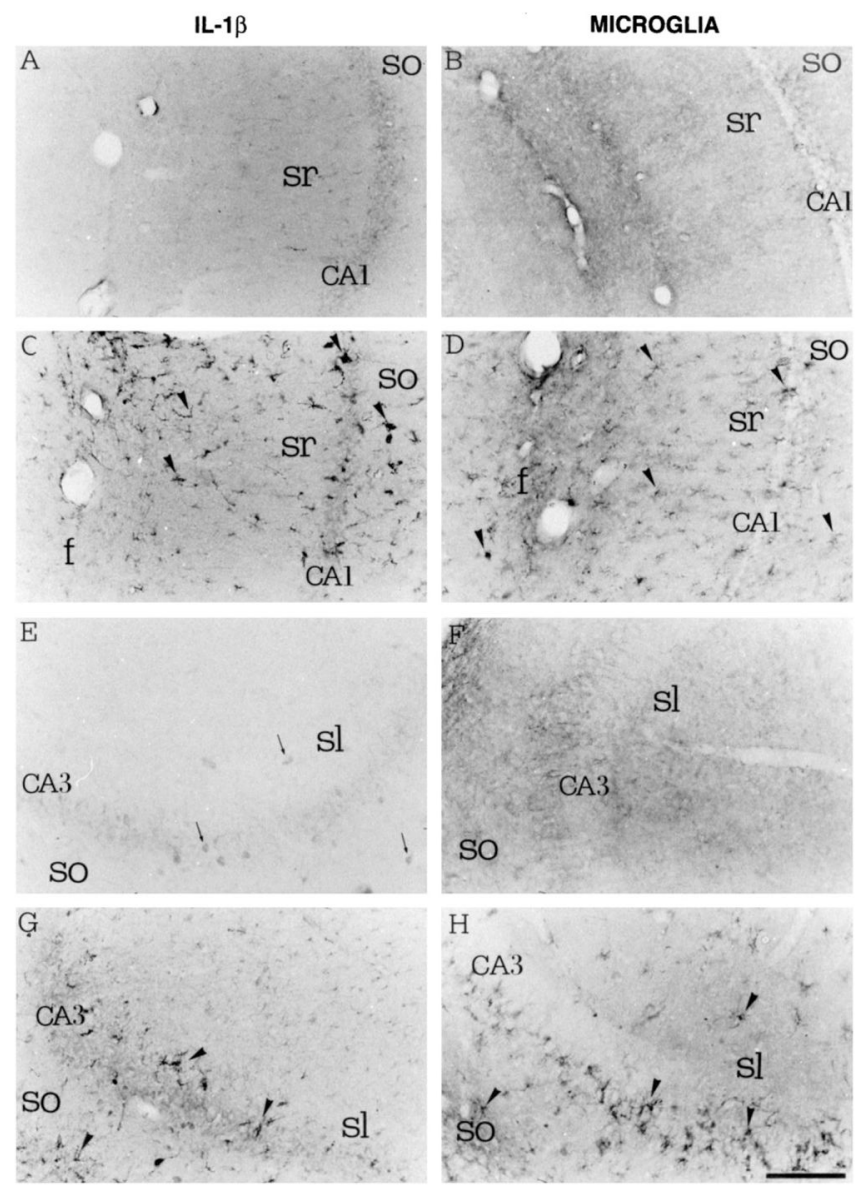

Fig. 1.

Cytokine induction and microglial activation in the hippocampus after local injection of kainic acid. Left panels show IL-1 $\beta$ immunoreactivity; right panels show microglia revealed by B4-isolectin immunoreactivity. (A and B) Control saline injection in the CA1 area of the hippocampus. (C and D) Kainic acid injection in the same area. (E and F) Control saline injection in the $\mathrm{CA} 3$ area of the hippocampus. $(\mathrm{G}$ and $\mathrm{H}$ ) kainic acid injection in the same area (from [161] with permission). 


\section{A Control Seizures}

IL-1

Actin

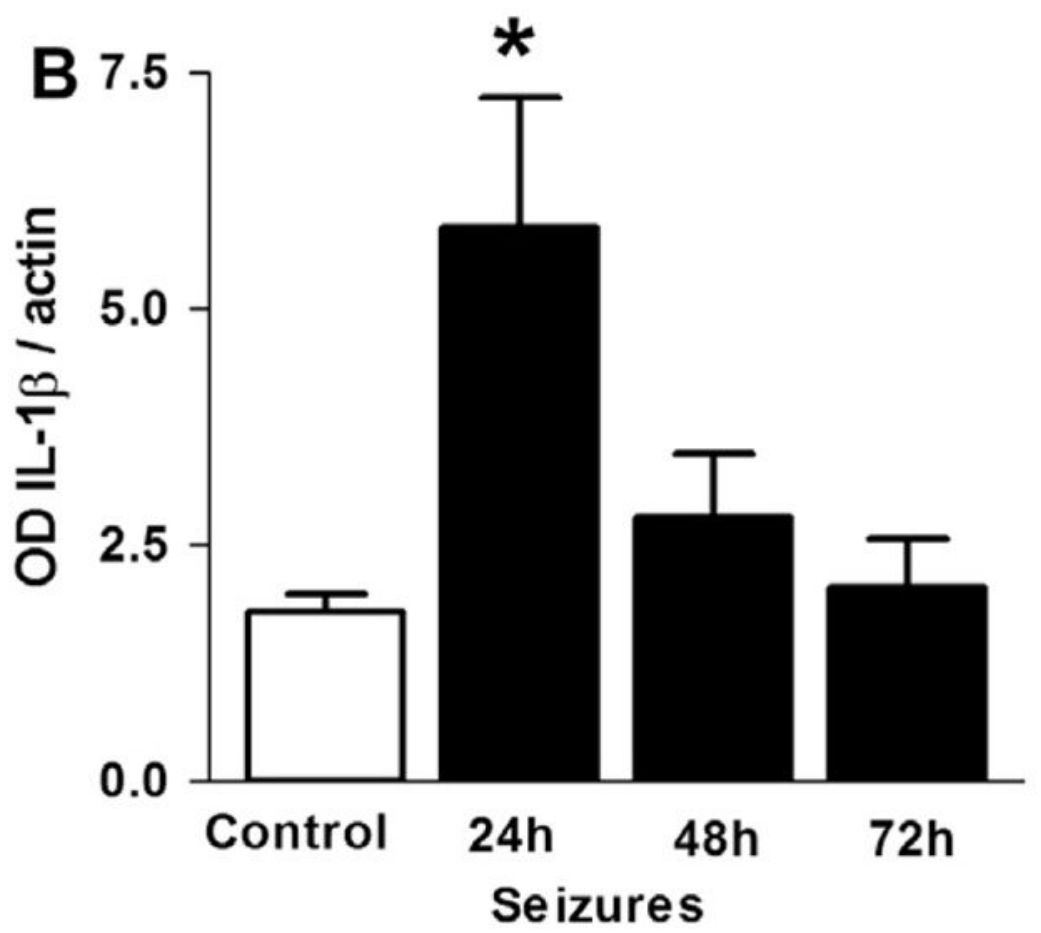

Fig. 2.

A seizure in a neonatal rat results in transient elevation of IL-1 $\beta$ in the hippocampus. (A) Representative Western blots showing increasing IL- $1 \beta$ protein following a febrile seizure. (B) Quantitative analysis of IL-1 $\beta$ protein levels 24,48 and $72 \mathrm{~h}$ following seizure induction (from [40] with permission). 

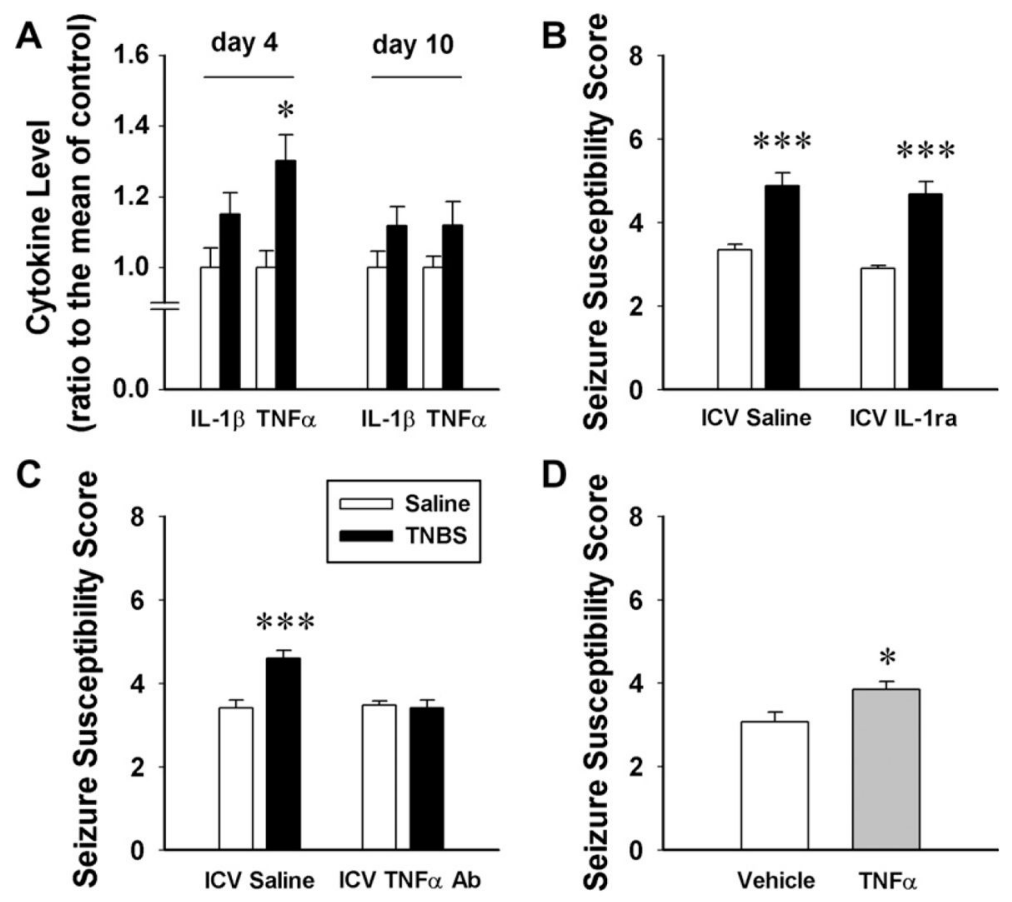

Fig. 3.

Peripheral inflammation induces hippocampal cytokine synthesis and increases seizure susceptibility in a TNFa dependent manner. (A) At the peak (day 4) of experimental colitis induced by intracolonic infusion of TNBS (black bars) TNFa levels are elevated. (B) Seizure susceptibility is enhanced in colitic rats and intracerebroventricular (ICV) infusion of IL-1ra does not interfere with this. (C) In contrast, ICV TNFa antibody administration blocks the increased seizure susceptibility. (D) ICV TNFa alone increases seizure susceptibility in naïve rats (from [127] copyright $@ 2008$ by the National Academy of Sciences of the USA). 

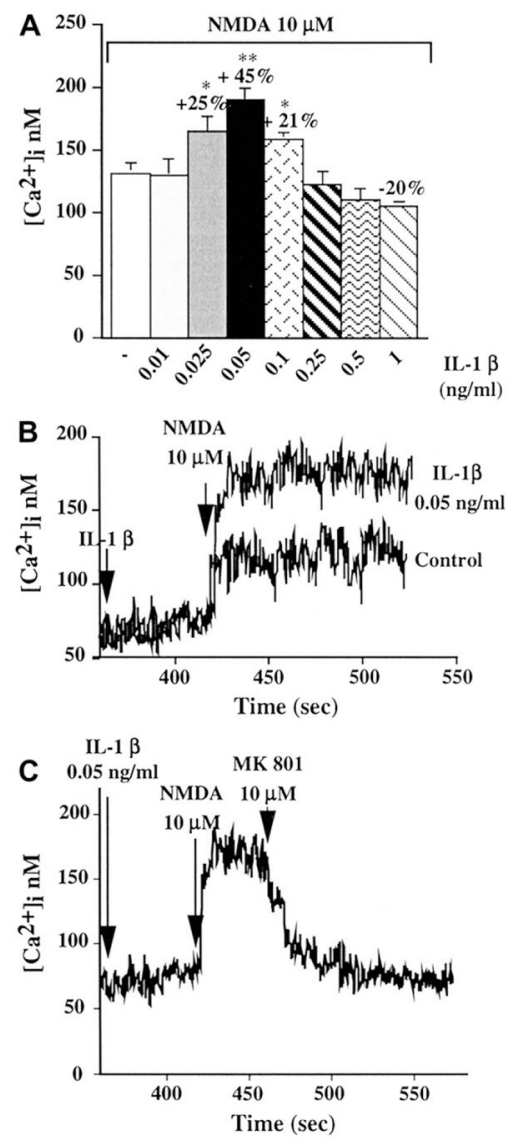

Fig. 4.

IL-1 $\beta$ augments NMDA effects in cultured hippocampal neurons. (A) Peak calcium responses to NMDA after brief (6 min) pre-exposure to various doses of IL-1 $\beta$. (B) Representative data showing increased calcium levels after NMDA in the presence of IL-1 $\beta$. (C) The effect of IL-1 $\beta$ on NMDA induced calcium increases was via an action at the NMDA receptor as it was blocked by the NMDA receptor antagonist MK 801 (from [165] with permission). 

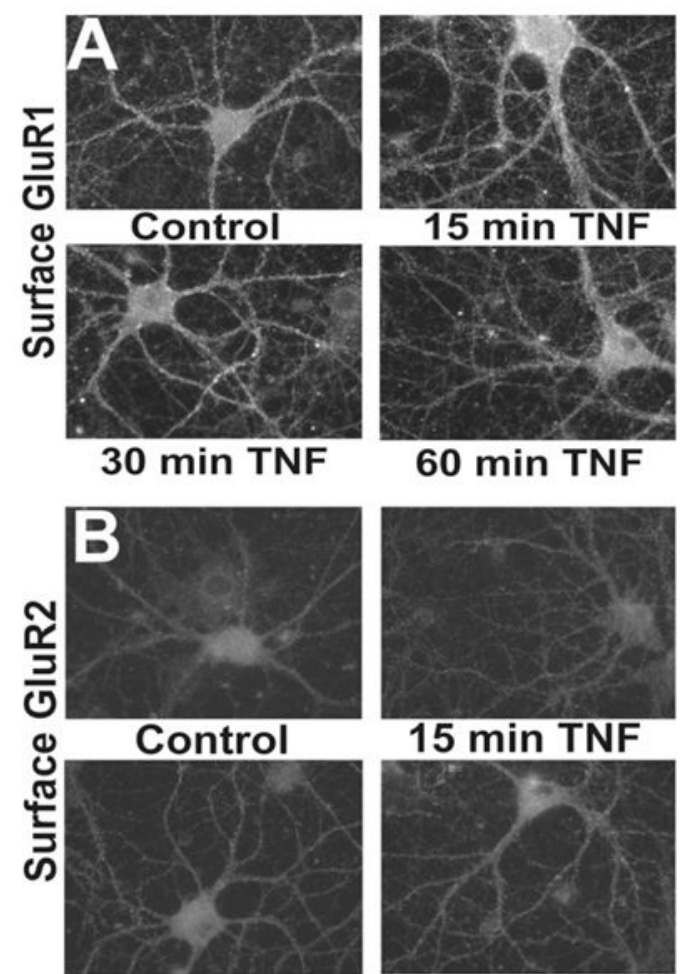

15 min TNF

$30 \mathrm{~min}$ TNF

$60 \mathrm{~min}$ TNF

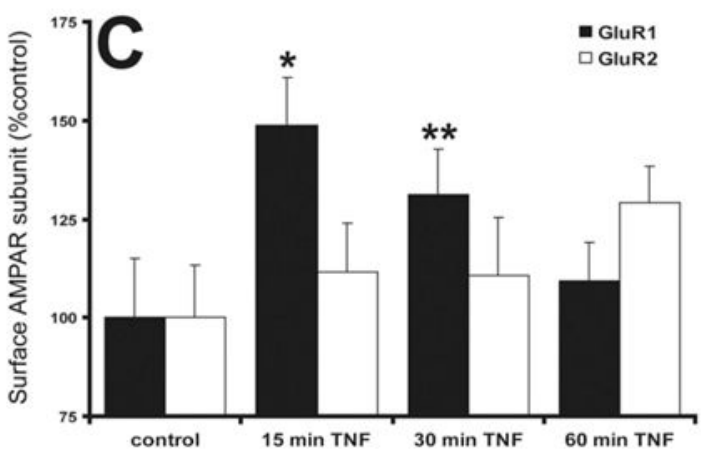

Fig. 5.

TNFa induces a transient increase in surface expression of GluR2 lacking AMPA receptors at the cell surface of hippocampal neurons. (A) Immunofluorescent detection of surface GluR1 receptors in response to application of $\mathrm{TNFa}$ in culture. (B) A similar experiment shows that GluR2 containing AMPA receptors do not move to the membrane in response to TNFa. (C) Compiled data indicating rapid and reversible surface expression of GluR2 lacking AMPA receptors after TNFa (from [93] with permission). 